Soviet Union to supply nuclear reactors to India New Delhi

THE Soviet Union will build India's biggest nuclear power station, consisting of two $1,000-\mathrm{MW}$ reactors, under an agreement signed on 20 November by Prime Minister Rajiv Gandhi and President Mikhail Gorbachev. A one-year pact on cooperation in exploration and use of outer space was also signed during Gorbachev's second visit to New Delhi.

The two Soviet VVER-type pressurized light water reactors will be located in the coastal town of Koodangulam in Tamil Nadu state. The reactors will be operaional in the late 1990s and their import is the first by India since Canada and the United States severed nuclear ties in the aftermath of the Pokran nuclear test in 1974.

India has accepted the Soviet plants nearly eight years after the offer was first made by Leonid Brezhnev. India's own programme has been based on a Canadian design (CANDU) that uses locally available uranium and heavy water. The Sovietbuilt station will depend on imported enriched uranium fuel and newly trained operators.

The Soviet Union will build the reactors on a turnkey basis and supply fuel for their entire operational life. The spent fuel will be taken back by the Soviet Union. The Soviet Union will be committed to provide fuel irrespective of any future change in domestic laws - the United States stopped its fuel supply to the Tarapur reactors after the Indian nuclear test.

The Soviet-built atomic station will be under safeguards and will not be used for making nuclear weapons under a separate agreement with the International Atomic Energy Agency (IAEA). India had earlier accepted IAEA inspection in respect of the US-built Tarapur reactors and Canadianbuilt units near Kota in Rajasthan.

The addition of two more reactors to the 'safe-guarded' list is seen by some as erosion of India's nuclear self-reliance and sovereignty. The DAE secretary, Dr M. R. Srinivasan, has however said that the introduction of Soviet technology will have no adverse impact on his department's plans to build 25 or 30 CANDU reactors by the year 2000.

The long-term agreement on space signed by foreign ministers of both countries is an extension of the cooperation that began in 1963. It covers all areas in space science, space technology and applications. Specifically, there will be joint projects to study middle atmosphere and development of spaceborne microwave sensors. The Soviet Union will launch India's second remote sensing satellite IRS-IB in 1991.

K.S. Jayaraman

\title{
Harvard University attacked over ties with industry
}

\section{Boston}

Aт a press conference at Harvard University last week, consumer activist Ralph Nader unveiled two reports documenting the extent of Harvard faculty members' ties to industry and accused the university of "incremental, relentless corporatizaion". The reports*, issued by a studentrun, Nader-sponsored organization called 'Harvard Watch', disclose many instances of "conflicting commitments" by faculty members, and call upon the university to disclose publicly all corporate affiliations at the school.

According to the reports, Harvard faculty members are more involved in outside work with corporations and government than their peers at any other university in the United States. The reports claim, however, that these corporate affiliations are shrouded in secrecy, making information about them very difficult to obtain. Because of the lack of public scrutiny, conflicts of interest can often go undetected.

The reports cite the recent case of Scheffer Tseng, a researcher at a Harvardaffiliated hospital who, the university has acknowledged, was involved in a conflict of interest in clinical trials of an eye ointment for a company he helped to found (see Nature 335, 754; 1988). Harvard Watch criticized the university for knowing about Tseng's apparent conflict of interest but failing to disclose it publicly for at least five months before the case was first publicly exposed by the press.

Robert Weissman, the author of one of the Harvard Watch reports and an undergraduate senior at the university, stresses that the public expects disinterested expert advice from university professors. "We're not saying that university faculty shouldn't collaborate with industry", says Weissman, "but rather that students and the general public have a right to know about these relationships." Weissman points out that, in addition to faculty members' individual relationships with corporations, research contracts between the university and industry are not publicly disclosed. On the basis of limited financial information reported by Harvard, the Harvard Watch group asserts that such contracts exist with dozens of large corporate concerns including the Council for Tobacco Research, DuPont, Johnson and Johnson, R. J. Reynolds, Stroh Brewery and Union Carbide.

Nader expressed his concern that the university's principles of openness and availability of information are becoming subordinated to "mercantile values" dominated by the "rules of trade secrecy". Faculty commitments to corporations, he said, rob students of the attention of faculty members, subvert the interests of research "subsidized by taxpayers" and threaten the "priceless heritage" of the university community. Nader says he hopes the reports on Harvard will "open the way for similar work at other universities". By reviewing the personnel on the boards of directors of the world's largest corporations, Harvard Watch has established that Harvard professors maintain 38 directorships with Fortune 500 companies, almost twice as many as are held by Massachusetts Institute of Technology faculty, the next nearest university competitor. In addition, the report cites specifically the dramatic increase in industry ties in the biological sciences over the past decade, with more than 60 faculty members now holding positions at biotechnology companies.

In a brief statement issued by the university in response to Nader's charges, Harvard spokesman Peter Costa stated that "relationships between universities and industry serve the public interest" and that the university is "committed to proceeding with such relationships thoughtfully". In its official statement, however, the university declined to comment on Harvard Watch's specific charges, in particular the call for public disclosure, claiming that the university has not had time to evaluate the charges and pointing to what they consider to be "extensive rules governing conflicts of interest or commitment by faculty members".

Harvard biologist and Nobel laureate Walter Gilbert says that coporate ties provide a number of benefits "including a variety of intellectual stimulation to faculty members". But Gilbert, who stressed that he had not seen the actual Harvard Watch reports, says he sees no reason why the university's or individual faculty members' corporate relationships should not be made public. "My own view is that any corporatesponsored research should be open", he says. "Faculty members do have a number of reasons to collaborate with corporations, but there is no reason that those should be secret."

The greater danger, according to Gilbert is the university's involvement in a marketing venture, Ion, Inc. (see Nature 335, 291; 1988) which seeks to allow the university to profit from research at the medical school by bringing products to the market. Gilbert says that he thinks the university's reasons for establishing the venture are "foolish" and that it could lead to a "reduced ability to judge a conflict of interest". Seth Shulman

* Scholars. Inc: Han ard Academics in Service of Industry and Goternment, and The New Classified Research: Corporate Sponsored Biomedical Research and the Reign of Secrecy at Harvard Universitv: both from Harvard Watch. Cambridge, Massachusetts. November 1988. 